\title{
Early clinical pathologists: Robert Koch (1843-1910)
}

S R Lakhani

Department of Histopathology, St George's Hospital, London

S R Lakhani

Correspondence to: Dr S R Lakhani, Department of Histopathology Haddor Laboratories, Royal Marsden Hospital Downs Road, Sutton, Surrey SM2 5PT

Accepted for publication 18 December 1992

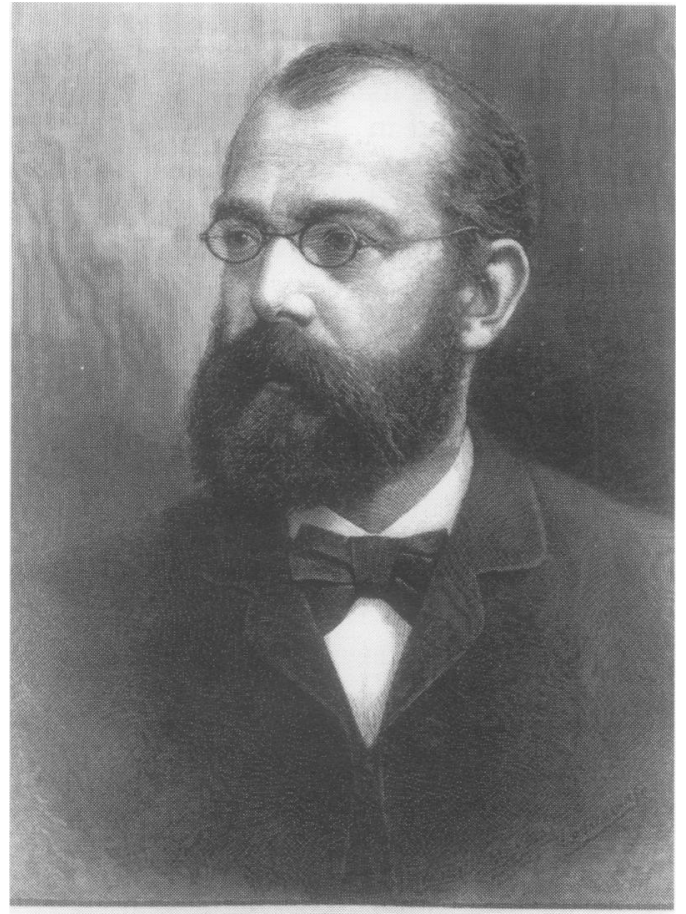

Figure 1 Portrait of Robert Koch courtesy of The Wellcome Institute for the History of Medicine.

The Bacillus Tuberculosis The history of the discovery of the bacillus presents many points of interest. Confidently expected by such observers as Villemin, Chauveau, Cohnheim, and others, and claimed to have been demonstrated by many, notably by Klebs and Aufrecht, it remained for Koch to demonstrate its existence and its invariable association with the disease....It forms one of the most masterly demonstrations of modern medicine. Its thoroughness appears in the fact that in the nine years which have elapsed since its announcement the innumerable workers at the subject have not, so far as I know, added a solitary essential fact to those presented by Koch.

William Osler, $1892^{1}$

Robert Koch was born in Clausthal on 11 December 1843. He came from a large family of 13 children-11 boys and two girls. His early schooling was at the Clausthal Gymnasium . He took a full and active part in school life and is reputed to have been an excellent athlete. During these years, he also accompanied his father, a mining engineer, on long walks and rides and developed an avid interest in natural science. His father had intended him to be a merchant but Robert had other ideas, and in 1862 he enrolled at Göttingen to study medicine. The University of Göttingen was no ordinary place and the faculty at the time included a number of men who were destined to leave their stamp on medical history. They included the pathologist Wilhelm Krause, the physiologist George Meissner, and the anatomist and histologist Jacob Henle. Henle in particular formed a close friendship with Koch and was a powerful influence on the young student.

In 1865 Robert Koch won a prize for a dissertation on uterine nerves and in that same year was appointed assistant to the Pathological Museum, a post that gave him considerable experience in pathology and microscopy. He also managed to find time to carry out original research with Meissner at the Physiological Institute, examining the effect of meat and fat on the excretion of succinic acid. Scientists seem to have a fascination with autoexperimentation, John Hunter being a classic example. ${ }^{2}$ Robert Koch was no exception. He decided to eat $1 / 2 \mathrm{~kg}$ of butter everyday and measure the concentrations of succinic acid in his urine. Not surprisingly, it made him so sick that he soon gave up the idea.

He qualified in 1866 and immediately became assistant in the General Hospital, Hamburg. The decision to work in Hamburg was based on social reasons. His initial wish was to become a ship's doctor and roam the world but he also wanted to marry his childhood sweetheart, Emmy Fraatz. Marriage would mean social responsibility and a need for financial security, hence the decision to start his medical practice. The position did not, however, provide a suitable income and three months later, he took up the post of physician to the Asylum for Idiots in Langenhagen, near Hanover and remained there till 1868. He married Emmy Fraatz on 16 July 1867 in the church at Clausthal. After leaving his job in Langenhagen, he enlisted for the Franco-German war and on his return in 1872, took up the position of Kreisphysicus, district physician, in the town of Wollstein. It was here that Koch began the work that was to revolutionise the practice of bacteriology.

Despite remaining for years in what was a rural country practice, away from the influence of university affairs, he managed to maintain the discipline, and more importantly, the enthusiasm, for research. Having started his country practice, Robert Koch organised a laboratory for himself with a 


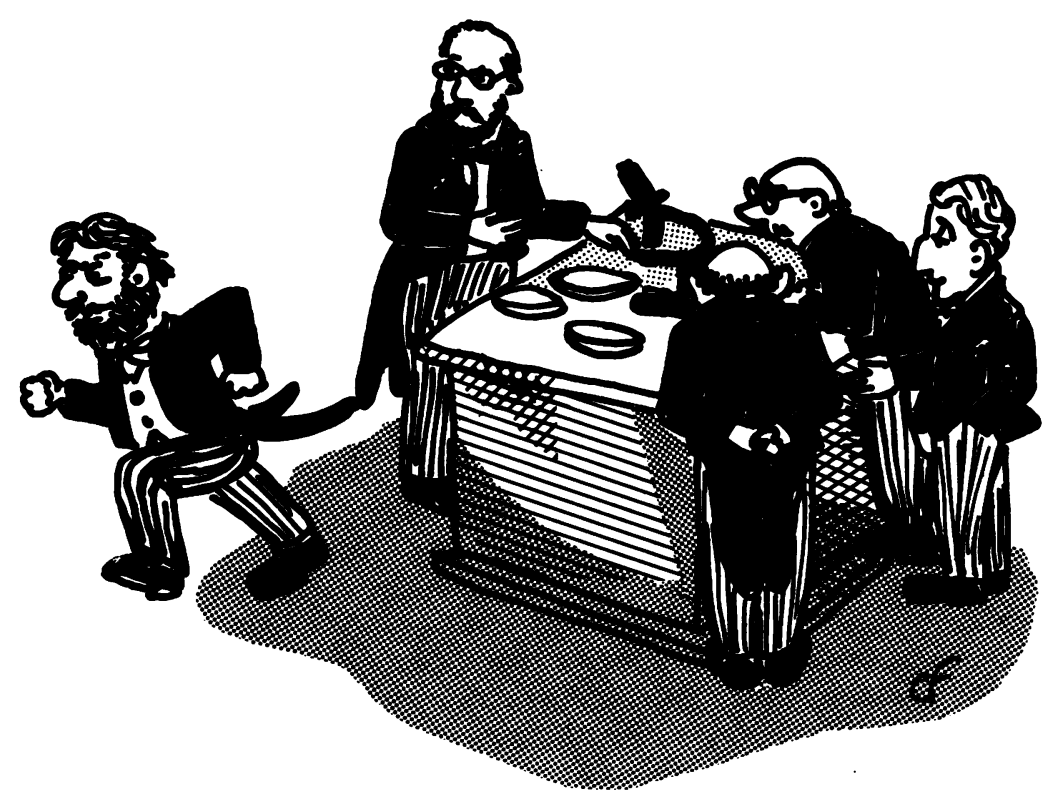

Figure 2 Courtesy of Dr C Finlayson, Department of Histopathology, St George's Hospital Medical School. anthrax bacillus and on the basis of that, the nature of the disease could be fully explained. Cohn sent an urgent invitation to Koch, asking him to come over to Breslau to demonstrate his experiments. On 30 April, 1876, the Botanical Institute witnessed a historic three day demonstration of Koch's experiments which was the first description of a complete life cycle for any bacteria. Besides Cohn, a number of other eminent people were present during the demonstrations including Leopold Auerbach and Julius Cohnheim. It is said that Cohnheim was so impressed with the work that he ran back to the Pathological Institute and brought back all the assistants to see the experiments for themselves.

He has also said of Koch's work, "I regard it as the greatest discovery in the field of pathology, and believe that Koch will again surprise us and put us all to shame by further discoveries." 3 Koch's work was published in Cohn's Beiträge zur Biologie der Pflanzen in July 1876 and with it came the birth of modern bacteriology.

Koch is also well known for his work with the tubercle bacillus (Koch's bacillus). The remarkable aspect of his work was the speed with which he accomplished it. He began his first experiments in August 1881 and less than eight months later, presented his findings to the Berlin Physiological Society. The lecture was published three weeks later with the full details of the experiments appearing in 1884 .

Tuberculosis was not a new disease; even Hippocrates had been aware of pulmonary tuberculosis. Miliary tuberculosis was also recognised but despite great advances in pathology, many, including Rudolf Virchow, believed that miliary and pulmonary tuberculosis were different diseases. When Koch started his work, there was evidence that tuberculosis was a contagious disease and transmissible to experimental animals, but a causal organism had not been identified. It was left to Koch to elucidate the life history of the bacillus and show its association with the disease, hence opening up the way for preventive measures. Interestingly, at this initial stage, he believed wrongly that the human and animal diseases were caused by the same organisms and that bovine tuberculosis was a real threat to human beings. His continued study of this disease helped him to modify his views in the latter years.

From the medical student's point of view, Koch's name is associated with Koch's postulates. It was in 1890 in Berlin, at the International Medical Congress, that he established these dictates. The postulates state that before an organism can be said to be the cause of the disease, it must fulfil certain criteria. The organism must be found in every case of the disease, it should be possible to isolate the organism in pure culture, and reintroduction of the organism should reproduce the disease. If these criteria are fulfilled, there must, by implication, be a causal relation between the organism and the disease. These principals may appear simple and obvious, but they constitute a major advance in progress, it would be essential to make pure cultures of the organisms.

On 22 April, 1876, he received a letter from a country physician stating that he had worked out the complete life history of the 
scientific thinking and exactness in research

With the growth of his reputation, it became more and more difficult for Koch to remain in the small town of Wollstein, and Cohn and his colleagues organised for him a post as municipal physician in Breslau. Koch did not enjoy his new position and after three months moved back to his former town, much to the delight of the people of Wollstein. He was, however, too big for the place and soon a position was found for him in Berlin where he took up the chair. A great deal of work was carried out during his time in Berlin and many of the techniques for sterilisation and for culturing organisms were developed and introduced during this period.

Robert Koch's achievements were not confined to his native land. He travelled extensively with the aim of investigating the infectious diseases that were the cause of so much mortality. In 1883 he headed the Cholera Commission which took him first to Egypt and then to India. France had also sent out a commission to Africa to investigate the same problem, but it was Koch who returned triumphant and he is given the credit for the discovery of the vibrio cholera and showing its relation to the disease, and working out its modes of transmission. When cholera broke out in France, Koch was invited to investigate it, much to the annoyance and distaste of Louis Pasteur. The Koch-Pasteur controversy, which had been going on for some time, cannot have been helped by this episode. The controversy between the two men is rooted in French-German antagonism at the time as well as in misunderstandings caused by the difficulties with language. It is too complicated and involved to untangle in a short article but is well covered in Brock's excellent book. ${ }^{4}$ The strength of the feeling between them is well illustrated by Koch's reply to the lecture by Pasteur in Geneva in 1882:

"When I saw in the program of the Congress that $M$ Pasteur was to speak today on the attenuation of virus, I attended the meeting eagerly, hoping to learn something new about this very interesting subject. I must confess that I have been disappointed, as there is nothing new in the speech which $M$ Pasteur has just made. I do not believe it would be useful for me to respond here to attacks which $M$ Pasteur has made on me, for two reasons: first, because the points of disagreement between Pasteur and myself relate only indirectly to the subject of hygiene, and second because I do not speak French well and $M$ Pasteur does not speak German at all, so that we are unable to engage in a fruitful discussion. I will reserve my response for pages of the medical journal." (Applause).

Pasteur responded by saying that if Koch had been able to follow him, he would have easily seen that new material was indeed presented. ${ }^{5}$

In 1896 Koch travelled to South Africa. $\mathrm{He}$ was invited by the Cape government to investigate Rinderpest. His stay was sponsored by the De Beer's Company and the Kimberley Diamond Fields Advertiser gave dra- matic reports of his progress. ${ }^{6}$ On his return, he published articles on malaria and black water fever. He returned to Africa, this time German East Africa in 1902 to study parasitic diseases caused by the tse tse fly, and in 1906 he headed the commission on sleeping sickness. These are just a few of the many projects that Koch was involved in, and in each he made a significant contribution to our knowledge of that disease. But not everything he touched turned to gold. Koch's greatest disappointment was with the production of tuberculin. He described its preparation in 1890 and had great hopes for it. It was heralded as a specific treatment of tuberculosis and Koch genuinely believed that it would wipe out the disease. Although the therapeutic benefits did not meet the expectation, it was still a very important medical advance.

Koch changed jobs a number of times in the later years. In 1885 he became Professor of hygiene and bacteriology in the University, a post that was created for him, and in 1891 he became director of the Institut für Infectionskrankheiten in Berlin, the institute having been built under his direction. He stayed here till 1901 and was succeeded by his pupil, Gaffky. Koch's reputation had spread all over the world and his laboratory was always full of doctors and scientists from America, England, Italy, and from all over Germany. He taught or indirectly influenced many of the leading men in the world of medicine-Loeffler, Behring, Wassermann, Laplace and Gaffky to name a few.

Koch's later years were blighted with deteriorating health and great disappointment about the failure of tuberculin. He had also not been on good terms with his wife, Emmy, for many years. At about the time of the tuberculin crisis, he had met a young art student, Hedwig Freiburg, who managed to rekindle some of his old spirit. He married her in September 1893 and she accompanied him on many of his travels abroad. He began to suffer from cardiac failure in 1910 and died later that year on 27 May at the age of 67.

Infectious diseases are still with us and no doubt they will continue to be so. What Robert Koch did was to set bacteriology on a new road on which it was possible to understand the life cycle of organisms, to be able to make pure cultures, and therefore to understand the biology and pathology of infectious diseases. Paul Ehrlich's words perhaps best sum up his great contribution to medicine and pathology: "...our entire knowledge of the infectious diseases and the various related branches of learning rests upon the foundations which he established..."

1 Osler W. The Principals and Practice of Medicine. New York: D Appleton and Company. 1892:185

2 Lakhani S. Early clinical pathologists: John Hunter. $f$ Clin Pathol 1991;44:621-3.

3 Wagner E. Introduction to Cohnheim, Julius F. Gesammelte Abhandlungen. A. Hirschwald Verlag, Berlin; 1885.

4 Brook TD. Robert Koch. A life in medicine and bacteriology Madison: Science Tech Publishers, 1988.

5 Pasteur L. De l'attenuation des virus. Quatrième Congrès International d'Hygiène et de Dèmographie, Genève 1882; Volume I: 145.

6 Blumberg L. Robert Koch and the rinderpest. South African Med $\mathcal{F} 1989 ; 76: 438-40$. 